\title{
Development and Evaluation of Low Gluten Composite Bread from Sorghum Cultivars
}

\author{
G.D. Arlene-Christina ${ }^{*}$, D.B. Kulkarni and B. Dayakar Rao
}

ICAR - Indian Institute of Millets Research, Hyderabad, Telangana, India

*Corresponding author

\section{A B S T R A C T}

This study examined the effects of sorghum flour incorporation in the production of low gluten composite bread. Three cultivars namely M 35-1, CSH 13 R and DSV 4 were taken and compared with refined wheat flour (Maida) in terms of particle size, moisture, water activity, alcoholic acidity and falling number, etc. It was found that CSH $13 \mathrm{R}$ passed $99.88 \%$ through 30 microns sieve which was closely related to Maida. Moisture content in cultivar M 35-1 was almost equal (8.62) than that of Maida (8.94). Water activity and alcoholic acidity were found highest in M 35-1 (0.7360) and (0.0743) and lowest in DSV 4 $(0.5764)$ and $(0.0520)$ respectively. DSV 4 showed highest falling number (536) compared to Maida (384). The damaged starch percent of the cultivar CSH 13R was highest (4.99\%) among the cultivars studied. Composite bread was made using two combinations of sorghum flour (20 and 30\%) with refined wheat flour (Maida). The samples coded (T1, T2 $(20 \%, 30 \% \mathrm{M} 35-1), \mathrm{T} 3, \mathrm{~T} 4(20 \%, 30 \% \mathrm{CSH} 13 \mathrm{R}), \mathrm{T} 5, \mathrm{~T} 6(20 \%, 30 \% \mathrm{DSV} 4)$ and $\mathrm{T} 7$ $100 \%$ maida). Bread samples were analyzed for weight specific volume, moisture, water activity, alcoholic acidity, etc. Crumb firmness was analyzed with texture profile analysis. The sensory evaluation of samples revealed higher scores for overall acceptability for sample T3 (7.5) (20\% CSH 13 R). It is clear from the above study that good quality bread can be made with $20 \%$ sorghum flour having particle size of 30 mesh.

\section{Introduction}

Bread is an important staple food in both developed and developing countries. Worldwide bread consumption accounts to be one of the largest consumed foodstuffs, with over 9 billion $\mathrm{kg}$ of bread being produced annually. This demand has been driven by consumers seeking convenient fresh products that provide a source of nutritional value (Hebeda and Zobel, 1996). Wheat (Triticum aestivum) flour of both hard and soft wheat classes has been the major ingredient of leavened bread for many years because of its functional proteins. However, bread can only be made from imported high gluten wheat which is not suitable for cultivation in the tropical areas for climatic reasons (Edema et al., 2005). Several developing countries have encouraged the initiation of programs to evaluate the feasibility of alternative locally available flours as a substitute for wheat flour. 
Many efforts have been carried out to promote the use of composite flours, in which a portion of wheat flour is replaced by locally grown crops, to be used in bread, thereby decreasing the cost associated with imported high gluten wheat (Olaoye et al., 2006). Most of the research conducted on the use of composite flour for bread making. Adeyemi and Idowu, (1990); Dhingra and Jood, (2004); Hsu et al., (2004); Khalil et al., (2000); McWatter et al., (2004) studied the effects of different flour substitutions on bread making quality. Acceptability studies conducted at the Food Research Centre in Khartoum, Sudan, indicated that breads made with composite flour of $70 \%$ wheat and $30 \%$ sorghum were acceptable (FAO, 1995). Consumer acceptance trials in Nigeria indicated that breads made with $30 \%$ sorghum flour were comparable to $100 \%$ wheat bread (Aluko and Olugbemi, 1989; Olatunji et al., 1989).

Sorghum (Sorghum bicolor L. Moench) is an important cereal and is one of the chief food crops in dry lands of tropical Africa, India and China (Shobha et al., 2008). India ranks second in the world for sorghum production and first with respect to many regionally important crops like millets and pseudocereals. Sorghum is the principal staple food of Maharashtra and is also an important food of Karnataka, Madhya Pradesh, Tamil Nadu and Andhra Pradesh. Sorghum can be milled to produce flour and grits (semolina) from which many ethnic and traditional dishes can be made. The most common products are leavened and unleavened breads, porridges, boiled grains and steam cooked products. Sorghum is often recommended as a safe food for celiac patients because gluten is more closely related to maize than wheat, rye, and barley (Kasarda 2001). Sorghum might therefore provide a good range for gluten-free products. However, the bulk of studies dealing with leavened breads containing sorghum have focused on composite breads from wheat and sorghum, in which a maximum of only $30 \%$ sorghum is regarded as acceptable (Munck 1995).

It was therefore felt worthwhile to formulate and standardize nutrient rich, high quality composite sorghum bread in combination with wheat with increased sensorial acceptance.

\section{Materials and Methods}

The raw materials like sugar, refined wheat flour, salt, active dry yeast were purchased from local market Hyderabad (TS, India). The chemicals used were availed from Himedia chemicals pvt. Ltd. Three sorghum cultivars (CSH-13R, M 35-1 and DSV 4) were made available from Indian Institute of Millets Research, Rajendranagar Hyderabad (TS, India) where the research was carried out. The replicates $(n=3)$ of each cultivar were analyzed.

\section{Particle size distribution}

A sieve analysis is a practice commonly used in engineering to assess the particle size distribution of a granular material (Sonaye and Baxi, 2012). Particle size distribution for all cultivars was carried out using different mesh sizes i.e. 600 microns (30 mesh), 250 microns (60 mesh) and 180 microns (85 meshes).

\section{Starch damage test for flours}

The damaged starch percentage of the flour was determined using method (AACC 76$30 A)$. $1 \mathrm{gm}$ of flour sample was weighed in $125 \mathrm{ml}$ Erlenmeyer flask. Enzyme buffer solution of $45 \mathrm{ml}$ containing $100 \mathrm{mg}$ of alpha amylase (Sigma chemicals, Ec No. 232-565-6) was added and mixed thoroughly. Mixture was incubated in thermostatically controlled water bath $\left(30^{\circ} \mathrm{C}\right)$ for $15 \mathrm{~min}$. At the end of 15 $\mathrm{min}, 3 \mathrm{ml}$ of $3.68 \mathrm{~N}$ Sulfuric acid and $2 \mathrm{ml}$ of $18 \%$ Sodium Tungstate solution were added 
and mixture was made to stand for $2 \mathrm{~min}$ and filtered. $5 \mathrm{ml}$ of filtrate was transferred to pyrex test tube $\left(25^{*} 200 \mathrm{~mm}\right)$ and $10 \mathrm{ml} 0.1 \mathrm{~N}$ alkaline ferric cyanide reagent added. The test tubes were immersed in boiling water for 20 min and then cooled rapidly. Then $25 \mathrm{ml}$ of acetic acid salt solution and $1 \mathrm{ml}$ of Iodine indicator were added. The contents were mixed properly and titrated against $0.1 \mathrm{~N}$ Sodium Thiosulphate solution. The $\mathrm{ml}$ of 0.1 $\mathrm{N}$ alkaline ferric cyanide reduced by the liberated reducing sugar was calculated to $\mathrm{mg}$ of Maltose equivalent. The amount of damaged starch was calculated by multiplying the mg maltose equivalent by a factor of 1.65 .

\section{Determination of Moisture, water activity, alcoholic acidity and falling number of flour}

Moisture of the flour was determined using the hot-air oven method (AACC44-15A, 2000). Water activity is determined using dew point sensor water activity meter (Aqua lab, 4TF). Alcoholic acidity was determined as per the method of Thapar et al., (1988) and falling number was determined using falling number apparatus (Bastak 5000).

\section{The baking recipe}

The bread was developed according to the method given by Sabanis et al., (2009) with some modifications. Active dry yeast $(1.5 \%)$ was dissolved first in warm water $(50 \mathrm{ml})$ with small amount of sugar (2\%) to increase the yeast activity. The content was stirred for 5 min to dissolve all the yeast lumps. The mixture was kept half an hour for fermentation After completion of yeast fermentation, sifted Maida, sorghum flour (20\% or $30 \%)$, salt $(1.5 \%)$, fat $(3 \%)$ and remaining sugar $(4 \%)$ were added. Dough was kneaded with addition of water $(75 \mathrm{ml})$ to the non-stick consistency. Dough was kept for $1 \mathrm{~h}$ undisturbed wrapped with a damp cloth to avoid surface drying.
When the volume of the dough gets double, it was divided into required weight pieces, rounded and again kept for fermentation for 15-20 min. Dough balls were then pressed with hand and rolled with sealing the ends. Prepared rolls were kept in warm temperature for proofing in the greased trays, covered on top for half an hour. Finally the trays were kept in the oven for baking at $230^{\circ} \mathrm{C}$ for $15-20$ min. The bread was cooled at room temp and sliced. The different formulations from the sorghum cultivars and the control (T1, T2, T3, T4, T5, T6 and T7) were prepared and taken for analysis (Table 1).

\section{Determination of loaf volume of composite bread}

The loaf volume of each bread sample was measured 50 minutes after the loaves were removed from the oven by using the rape-seed displacement method as described by Onwuka (2005).

\section{Texture Profile Analysis (TPA) for composite bread}

Bread texture (hardness, springiness, cohesiveness, chewiness, gumminess and resilience) was determined using Brookfield texture analyzer.

\section{Sensory evaluation of composite bread}

Sensory evaluations of composite bread samples were carried out using 9-point hedonic scale. The 10 numbers of trained taste panel was asked to rate the bread for their various sensory attributes like colour, taste, texture, mouth feel and overall acceptability as described by Larmond (1977).

\section{Statistical analysis}

The data was subjected to statistical analysis. Mean and standard deviation were computed. 
One way analysis of variance (ANOVA) was used to determine the mean differences between the different samples.

\section{Results and Discussion}

\section{Particle size distribution}

Flour particle size is an indication of the degree of fineness of a flour sample, as well as its total exposed surface area (Pratt 1978). The results in Table 2 shows that through 30mesh sieve $(595 \mu)$ the highest flour passing percentage was observed in CSH 13R (99.88) followed by DSV 4 (99.28) and M35-1 $(98.22 \%)$ than control $(99.90 \%)$. In $250 \mu$ sieve (60mesh) the highest percentage of flour passing was observed in M35-1 (88.65) whereas the lowest was DSV 4 (85.45).

CSH $13 \mathrm{R}$ was found (87.76) compared to control (89.34). In 180 microns (85mesh) the highest percentage was observed in the order of Maida (89.30)> CSH 13R (89.20)> DSV 4 (87.12) > M35-1(81.23). On an average, CSH $13 \mathrm{R}$ was found have more passing percentage through different sieves and at par with control. However, an additional reduction of particle size is typically associated with an increase in starch damage. Pratt (1978) investigated that the flour particle size exhibits independent effects on baking and bread quality. LeClerc, et al., (1919) and Shellenberger et al., (1950) have investigated the effects of wheat flour granulation and particle size on baking quality. The reports suggested by Yamazaki and Donelson (1972), and Chaudhary et al., (1981) showed a correlation between particle size and baking volume.

\section{Starch damage test for flour samples}

During grain milling, a portion of the starch granules sustains mechanical damage (Jones 1940). The level of the damage varies with the severity of grinding and the hardness of the grain (Hoseney, 1994a). Damaged starch granules hydrate rapidly and are susceptible to enzymatic hydrolysis (Ranhotra et al., 1993). A certain level of starch damage is desirable because it optimizes hydration and promotes fermentation activity during bread making. However, excessive starch damage can overly hydrate the dough and allows accelerated enzymatic action. Thus, it might result in sticky dough and cause problems with slicing and handling of the bread (Ranhotra et al., 1993). The good quality of bread can be prepared with a flour containing $10 \%$ of damaged starch. Hence the level of starch damage is an important quality index for the evaluation bread flours. The damaged starch percentage of sorghum cultivars presented in table 3 shows that there was no significant difference between CSH $13 \mathrm{R}$ and DSV 4 (4.99 and 4.95 respectively). The highest damaged starch percent was found in Maida $(8.8 \%)$ and the lowest was in M 35-1 (2.475). It was found that as the particle size decreases starch damage increases. This clearly indicates that CSH $13 \mathrm{R}$ and DSV 4 cultivars are better options for bread making compared to M 35 1. Better quality sorghum-wheat breads can be obtained by increasing the starch damage content to the desirable level in sorghum flour by appropriate milling methods.

\section{Determination of moisture content, water activity, alcoholic acidity and falling number}

Moisture content of the flour samples was found less than $10 \%$ (Table 4). Highest moisture was found in M35-1 (8.62) and was lowest in DSV 4 (8.23). The moisture content in $\mathrm{CSH} 13 \mathrm{R}$ was $8.56 \%$ and Maida was $8.94 \%$. Water activity was found in the order of Maida (0.518)> M 35-1(0.4902)> CSH 13 R (0.4863)> DSV 4 (0.3801). The alcoholic acidity of the cultivar M35-1 was 0.0743, DSV 4 (0.0520) and CSH $13 \mathrm{R}$ (0.0562) compared to control (0.0785). 
Table.1 Formulations used for preparation of sorghum-wheat composite bread

\begin{tabular}{|l|l|l|l|}
$\begin{array}{l}\text { Sample } \\
\text { No. }\end{array}$ & Cultivars/control & $\begin{array}{l}\text { Sorghum flour } \\
(\mathrm{g})\end{array}$ & Maida (g) \\
\hline T1 & M35-1 & 20 & 80 \\
\hline T2 & M35-1 & 30 & 70 \\
\hline T3 & CSH 13 R & 20 & 80 \\
\hline T4 & CSH 13 R & 30 & 70 \\
\hline T5 & DSV 4 & 20 & 80 \\
\hline T6 & DSV 4 & 30 & 70 \\
\hline T7 & Maida & 00 & 100 \\
\hline
\end{tabular}

Table.2 Particle size distribution for different sorghum cultivars

\begin{tabular}{|l|l|l|l|l|l|} 
S. No & Cultivars & \multicolumn{5}{|c|}{ Mesh sizes } \\
\hline $\mathbf{1}$ & $\begin{array}{l}\mathbf{6 0 0} \text { microns } \\
\text { mesh) }\end{array}$ & $\begin{array}{l}\mathbf{2 5 0} \text { microns } \\
\text { mesh) }\end{array}$ & $\begin{array}{l}\mathbf{1 8 0} \text { microns } \\
\text { mesh) }\end{array}$ \\
\hline 2 & $\begin{array}{l}\text { CSH } \quad \mathbf{1 3} \\
\text { R }\end{array}$ & $98.22 \pm 0.26$ & $88.65 \pm 0.14$ & $81.23 \pm 0.12$ \\
\hline $\mathbf{3}$ & DSV 4 & $99.28 \pm 0.11$ & $87.76 \pm 0.25$ & $89.20 \pm 0.10$ \\
\hline $\mathbf{4}$ & Maida & $99.90 \pm 0.02$ & $85.45 \pm 0.21$ & $87.12 \pm 0.23$ \\
\hline
\end{tabular}

Each value is the average of three determinations

Table.3 Damaged starch \% for different sorghum cultivars

\begin{tabular}{|l|l|l|}
\hline Sr. No. & Cultivar & Damaged starch \% \\
\hline $\mathbf{1}$ & M35-1 & $2.475 \pm 0.36$ \\
\hline $\mathbf{2}$ & CSH 13 R & $4.99 \pm 0.31$ \\
\hline $\mathbf{3}$ & DSV 4 & $4.95 \pm 0.29$ \\
\hline $\mathbf{4}$ & Maida & $8.8 \pm 0.10$ \\
\hline
\end{tabular}

Each value is the average of three determinations

Table.4 Chemical parameters of flours used for composite bread preparation

\begin{tabular}{|l|l|l|l|l|l|} 
Sr. No & Cultivars & $\%$ Moisture & $\begin{array}{l}\text { Water } \\
\text { activity }\end{array}$ & Alcoholic Acidity & $\begin{array}{l}\text { Falling } \\
\text { number }\end{array}$ \\
\hline $\mathbf{1}$ & M 35-1 & $8.62 \pm 0.14$ & $0.4902 \pm 0.021$ & $0.0743 \pm 0.008$ & $406 \pm 2$ \\
\hline $\mathbf{2}$ & $\begin{array}{l}\text { CSH 13 } \\
\text { R }\end{array}$ & $8.56 \pm 0.22$ & $0.4863 \pm 0.011$ & $0.0562 \pm 0.011$ & $395 \pm 4$ \\
\hline $\mathbf{3}$ & DSV 4 & $8.23 \pm 0.14$ & $0.3801 \pm 0.019$ & $0.0520 \pm 0.005$ & $436 \pm 2$ \\
\hline 4 & Maida & $8.94 \pm 0.18$ & $0.5184 \pm 0.021$ & $0.0785 \pm 0.004$ & $384 \pm 3$ \\
\hline
\end{tabular}

Each value is the average of three determinations 
Table.5 Loaf volume of composite bread

\begin{tabular}{|l|l|c|c|c|}
\hline $\begin{array}{l}\text { Sr. } \\
\text { No. }\end{array}$ & $\begin{array}{l}\text { Sample } \\
\text { No. }\end{array}$ & $\begin{array}{c}\text { Weight } \\
(\mathbf{g})\end{array}$ & $\begin{array}{c}\text { Loaf volume } \\
\left(\mathbf{c m}^{\mathbf{3}}\right)\end{array}$ & $\begin{array}{c}\text { Specific loaf } \\
\text { volume }(\mathbf{c m} 3 \mathbf{g})\end{array}$ \\
\hline $\mathbf{1}$ & T1 & $356 \pm 2$ & $1032 \pm 3$ & $2.90 \pm 0.1$ \\
\hline $\mathbf{2}$ & T2 & $360 \pm 3$ & $1015 \pm 5$ & $2.81 \pm 0.14$ \\
\hline 3 & T3 & $343 \pm 2$ & $1305 \pm 2$ & $3.81 \pm 0.19$ \\
\hline 4 & T4 & $350 \pm 2$ & $1280 \pm 1$ & $3.66 \pm 0.12$ \\
\hline 5 & T5 & $348 \pm 3$ & $1190 \pm 5$ & $3.42 \pm 0.21$ \\
\hline 6 & T6 & $360 \pm 1$ & $1175 \pm 2$ & $3.26 \pm 0.15$ \\
\hline 7 & T7 & $356 \pm 4$ & $1400 \pm 2$ & $3.96 \pm 0.16$ \\
\hline
\end{tabular}

Each value is the average of three determinations

Table.6 Texture characteristics of composite bread

\begin{tabular}{|l|c|c|c|}
\hline S. No & Hardness & Cohesiveness & \multicolumn{1}{|c|}{ Springiness } \\
\hline T1 & $377.5 \pm 1$ & $0.89 \pm 0.01$ & $9.48 \pm 0.02$ \\
\hline T2 & $389.6 \pm 2$ & $0.87 \pm 0.01$ & $9.47 \pm 0.03$ \\
\hline T3 & $332.5 \pm 1$ & $0.81 \pm 0.02$ & $9.46 \pm 0.01$ \\
\hline T4 & $349.2 \pm 1$ & $0.80 \pm 0.02$ & $9.41 \pm 0.02$ \\
\hline T5 & $460.0 \pm 2$ & $0.96 \pm 0.01$ & $9.51 \pm 0.01$ \\
\hline T6 & $472.2 \pm 2$ & $0.92 \pm 0.01$ & $9.50 \pm 0.03$ \\
\hline T7 & $351.0 \pm 1$ & $0.79 \pm 0.01$ & $9.37 \pm 0.01$ \\
\hline
\end{tabular}

Each value is the average of three determinations

Table.7 Sensory evaluation of composite bread

\begin{tabular}{|c|c|c|c|c|c|}
\hline $\begin{array}{c}\text { Sample } \\
\text { No. }\end{array}$ & Colour & Texture & Flavour & $\begin{array}{c}\text { Mouth } \\
\text { feel }\end{array}$ & $\begin{array}{c}\text { Overall } \\
\text { acceptability }\end{array}$ \\
\hline T1 & $6.4 \pm 0.5$ & $6.3 \pm 0.1$ & $6.8 \pm 0.2$ & $7.0 \pm 0.1$ & $6.7 \pm 0.1$ \\
\hline T2 & $6.2 \pm 0.4$ & $6.1 \pm 0.4$ & $6.4 \pm 0.2$ & $6.7 \pm 0.2$ & $6.4 \pm 0.2$ \\
\hline T3 & $7.4 \pm 0.8$ & $7.2 \pm 0.3$ & $7.6 \pm 0.1$ & $8.1 \pm 0.3$ & $7.5 \pm 0.4$ \\
\hline T4 & $7.2 \pm 0.2$ & $7.1 \pm 0.1$ & $7.0 \pm 0.3$ & $7.4 \pm 0.4$ & $7.2 \pm 0.3$ \\
\hline T5 & $6.1 \pm 0.1$ & $5.8 \pm 0.2$ & $6.0 \pm 0.1$ & $5.9 \pm 0.1$ & $6.0 \pm 0.1$ \\
\hline T6 & $5.9 \pm 0.3$ & $5.8 \pm 0.2$ & $6.1 \pm 0.2$ & $5.4 \pm 0.3$ & $5.7 \pm 0.2$ \\
\hline T7 & $7.5 \pm 0.2$ & $7.9 \pm 0.4$ & $8.1 \pm 0.1$ & $8.5 \pm 0.3$ & $8.5 \pm 0.3$ \\
\hline
\end{tabular}

Each value is the average of three determinations

Alcoholic acidity increases with increasing storage interval irrespective of all the packaging materials (Pradyuman Barnwal, et $a l ., 2013)$. As higher ingress of moisture by flour, the increase in alcoholic acidity will also be higher upon storage (Upadhyay et al., 1994). Falling number of flour samples were found as 406, 395, 436 and 384 for M35-1, CSH13 R, DSV 4 and control (Maida) respectively. More the falling number lesser the amylase activity and vice versa. Yeast in bread dough requires sugars to develop properly and therefore needs some level of enzyme activity in the dough. Too much 
enzyme activity means that too much sugar and too little starch are present. Since starch provides the supporting structure of bread, too much activity results in sticky dough during processing and poor texture in the finished product (Carl L. German 2006). The conclusion was made that amylase content has a key functional effect in the production of such a bread system (Hugo et, al., 1997).

\section{Determination of loaf volume of composite bread}

Loaf volumes of the samples were calculated and are presented in table 5 which reveals that bread samples $\mathrm{T} 1$ and $\mathrm{T} 2$ found to have lowest loaf volume readings (1032 and 1015 resp.) and thus having low specific volumes 2.90 and 2.81 respectively. T3 and T4 made with $\mathrm{CSH} 13 \mathrm{R}$ were shown highest loaf volumes and thus higher specific loaf volumes among all the three cultivars (1305 and 1380) and (3.81 and 3.66) respectively. Samples T5 and T6 show loaf volumes of 1190 and 1175 and specific loaf volumes of 3.42 and 3.26 respectively. The control sample T7 shows the loaf volume 1400 and specific loaf volume 3.96. It was observed experimentally that as the percentage of sorghum flour increases in the recipe, there is decrease in loaf volume and thus specific loaf volume (Abdelghafor, 2011). This might be due to large particle size and damaged starch percent of sorghum flour than Maida.

\section{Textural characteristics of composite bread}

Bread texture was determined using a Brookfield Texture Analyzer. The data presented in table 6 shows that, the amount of sorghum flours increased, the hardness of bread crumb increased. The replacement of wheat flour with sorghum flours decreased cohesiveness, and resilience in bread samples; however, it increased gumminess. The results of springiness (which indicates the percentage recovery of bread) indicated that when the substitution level of sorghum flours increased, the bread required more time to recover its shape. The results were found in coordination with the results of Abdelghafor, et al., (2011) Gumminess and chewiness are secondary parameters. Chewiness is the most indicative characteristic of bread. The results showed that gumminess increased with an increased amount of sorghum flours in the blends. Furthermore, results revealed that gumminess and chewiness values are highly dependent on hardness. It was reported that since wheat flours contain gluten protein which gives the bread its unique and much desired texture; the inclusion of sorghum flours dilutes wheat gluten, and consequently weakens its strength (Calvin Onyango 2011). Sample T3 (20\% CSH 13R) observed to be more suitable among other cultivars with respect to all the textural parameters and was found very close to Maida.

\section{Sensory evaluation of composite bread}

Sensory evaluation of composite bread prepared with various combinations of cultivars of sorghum flour discussed in table 7 reveals that the sensory scores for colour, taste, texture, mouth feel and overall acceptability of samples decreases with increase in concentration of sorghum flour in the recipe. The darkness in the colour of bread increased and thus sensory scores for colour parameter decreased from 7.5-5.9 in the respective samples. The sensory cores obtained for texture of bread shows significant change in the samples as the result of fiber content of the cultivars. Hence, it can be concluded that acceptable quality of composite bread prepared with $20 \%$ of sorghum flour was superior over samples with $30 \%$ sorghum flour. Among the samples with $20 \%$ sorghum flour, CSH $13 \mathrm{R}$ was found better results for overall acceptability (7.5). The results for sensory evaluation were found 
in good agreement with the findings of FAO (1995) and Abdelghafor et al., (2011) revealing that up to $20 \%$ wheat replacement with whole or decorticated sorghum flour produced acceptable pan breads.

The results of the study showed that acceptable quality composite bread can be developed with sorghum and refined wheat flour. The composite blends T3 and T4 showed desirable qualities such as loaf volume, textural and sensory properties that are suitable for commercialization and marketing.

\section{Acknowledgements}

The financial support received from ICARNational Agriculture Innovation Project (NAIP) is gratefully acknowledged.

\section{References}

AACC, 2000. Approved methods of American Association of Cereal Chemists. 10th Edn., AACC International, St. Paul, MN.

Abdelghafor, R.F Mustafa, A.I. Ibrahim A.M.H. and Krishnan P.G. (2011), Quality of Bread from Composite Flour of Sorghum and Hard White Winter Wheat, Advance Journal of Food Science and Technology 3(1): 9-15, 2011

Abdelghafor, R.F. Mustafa, A.I, Ibrahim A.M.H. and Krishnan, P.G. (2011) Quality of Bread from Composite Flour of Sorghum and Hard White Winter Wheat, Advance Journal of Food Science and Technology 3(1): 9-15, 2011

Adeyemi, I.A. and M.A. Idowu, 1990.Evaluation of pregelatinized maize in the development of maissa-a baked product. Nigerian Food J., 8: 63-73.

Aluko, R.E. and L.B. Olugbemi, 1989.Sorghum as a raw material in the baking industry. Paper presented at the Symposium on the Current Status and Potential of Industrial Uses of Sorghum in Nigeria. Kano, Nigeria. 4-6 December
Calvin Onyango, Christopher Mutungi b, Günter Unbehend C, Meinolf G. Lindhauer (2011) Rheological and textural properties of sorghum-based formulations modified with variable amounts of native or pregelatinised cassava starch, Food Science and Technology 44, 687e693

Carl L. German (2006) Understanding the Falling Number Wheat Quality Test, Food Resource and Economics, University of Dilaware.

Dhingra, S. and S. Jood, 2004.Effect of flour blending on the functional, baking and organoleptic characteristics of bread. Int. J. Food Sci. Technol., 39: 213-222.

Edema, M.O., L.O. Sanni and A.I. Sanni, 2005. Evaluation of maize-soybean flour blends for sour maize bread production in Nigeria. Afr. J. Biotechnol., 4: 911-918

FAO, 1995. Sorghum and Millets in Human Nutrition. FAO Food and Nutrition Series, No. 27. Retrieved from: http://www.fao. org/DOCREP/T0818e/T0818E00.htm\#Con tentsates.html.

Hebeda, R. E., and Zobel, H. F. (1996). Baked goods freshness: Technology, evaluation, and inhibition of staling. New York: Marcel Dekker.

Hoseney RC. (1994b). Principles of Cereal Science and Technology. 2nd Ed. St. Paul: American Association of Cereal Chemists, Inc. p 197-211.

Hoseney, R.C., 1994a. Dry Milling of Cereals, Principles of Cereal Science and Technology, American Association of Cereal Chemists, St. Paul, MN, USA, pp. 125-145.

Hsu, C.L., S.L. Hurang, W. Chen, Y.M. Weng and C.Y. Cheng, 2004. Qualities and antioxidant properties of bread as affected by incorporation of yam flour in the formulation. Int. J. Food Sci. Technol., 39: 231-238.

Hugo LF, Waniska RD, Rooney LW. 1997. Production of bread from composite flours. Harnessing Cereal Science and Technology for Sustainable Development. Pretoria, South Africa: CSIR ICC-SA Symposium $p$ 110-114.

Jones, C. R. 1940. The production of mechanically damaged starch in milling as 
a governing factor in the diastatic activity of flour. Cereal Chem. 17:133-169.

Kasarda, D. D. 2001.Grains in relation to celiac disease. Cereal Foods World 46:209-210.

Khalil, A.H., E.H. Mansour and F.M. Dawood, 2000. Influence of malt on rheological and baking properties of wheat-cassava composite flours. Lebensmittel Wissenchaf Technol., 33: 159-164.

Larmond, E., 1977. Method for sensory evaluation of food, Department of Agriculture, Canada, pp: 36-37.

LeClerc JA, Wessling HL, Bailey LH, Gordon WO. 1919. Composition and baking value of different particles of flour. Oper Miller 24:257-258.

McWatter, K.H., R.D. Philips, S.L. Walker, S.E. McCullough, Y. Mensah-Wilmot, F.K. Saalia, Y.C. Hung and S.P. Patterson, 2004. Baking performance and acceptability of raw extruded cowpea flour breads. J. Food Qual., 27: 337-351.

Munck, L. 1995. New milling technologies and products: Whole plant utilization by milling and separation of the botanical and chemical components. Pages 223-281 in: Sorghum and Millets: Chemistry and Technology. D. A. V. Dendy, ed. AACC International: St. Paul, MN.

Olaoye, O.A., A.A. Onilude and O.A. Idowu, 2006. Quality characteristics of bread produced from composite flours of wheat, plantain and soybeans. Afr. J. Biotechnol., 5: 1102-1106.

Olatunji, O., A.A. Adesina and O.A. Koleoso, 1989.Use of sorghum as composite flour in baking. Paper presented at the Symposium on the Current Status and Potential of Industrial Uses of Sorghum in Nigeria. Kano, Nigeria, 4-6 December.
Onwuka, G.I. (2005). Food Analysis. Naptithalis Prints, Lagos. Pp. 34-36.

Pradyuman Barnwal, PurushottamKore, Alka Sharma,(2013) Assessment of Storage Stability of Whole and Degermed maize flours, Internet Journal of Food Safety, Vol.15, 2013, p83-87

Pratt DBJ. 1978. Criteria of flour quality. In: Pomeranz Y, editor. Wheat Chemistry and Technology. St. Paul: American Association of Cereal Chemists, Inc. p 212.

Ranhotra, G.S., Gelroth, J.A., Eisenbraun, G.R., 1993. Correlation between Chopin and AACC Methods of determining damaged starch. Cereal Chemistry 70, 235 -236.

Sabanis, D., Lebesi, D., Tzia C., 2009. Effect of dietary fibre enrichment on selected properties of gluten-free bread, Food Science and Technology 42 (2009) 13801389

Shobha, V., Kasturiba, B., Naik, R. K. and Yenagi, N 2008.Nutritive Value and Quality Characteristics of Sorghum Genotypes. Karnataka Journal of Agriculture Science 20: 586-588

Sonaye, S.Y. and Dr. R. N. Baxi / particle size measurement and analysis of flour, International Journal of Engineering Research and Applications (IJERA) ISSN: 2248-9622 www.ijera.com Vol. 2, Issue 3, May-Jun 2012, pp.1839-1842 1839

Thapar VK, Sehgal VK, Paul S (1988) Post harvest quality analysis of food grains research bulletin. Department of Processing and Agricultural Structures, Punjab Agricultural University, Ludhiana, pp 1332.

Upadhyay RK, Thangaraj M, Jaiswal PK (1994) Storage studies of suji in different packages. Journal of Food Sci. Tech. 31(6): 494-496.

\section{How to cite this article:}

Arlene-Christina, G.D., D.B. Kulkarni and Dayakar Rao, B. 2018. Development and Evaluation of Low Gluten Composite Bread from Sorghum Cultivars. Int.J.Curr.Microbiol.App.Sci. 7(03): 728-736. doi: https://doi.org/10.20546/ijcmas.2018.703.085 